\title{
Research on Problems and Countermeasures of "Double Type" Teachers Team Construction in Applied Undergraduate Universities
}

\author{
Yan Li \\ Qingdao Huanghai University \\ Qingdao, Shandong, China \\ liyanvsl@126.com
}

\author{
Jiangbo Chen ${ }^{*}$ \\ Qingdao Huanghai University \\ Qingdao, Shandong, China \\ jiangbochen1981@163.com
}

\author{
Yuanyuan Xu \\ Qingdao Huanghai University \\ Qingdao, Shandong, China
}

\begin{abstract}
To construct a "double type" teacher team which can adapt to vocational education, is employment-oriented, and can strengthen the requirements of skills and practical teaching is the key to foster high-quality talents that the society needs, and also the main direction of teacher team building in applied undergraduate education. Based on this, we propose what is "double type" teacher, the significance of the construction of "double type" teachers, and how to build "double type" teachers. We analyze the meaning and existing problems of "double type" teachers team construction and propose countermeasures. The paper makes it clear that the construction of "double type" teachers in vocational education should further enhance the construction of the main force to comprehensively promote the construction of the team. Aim to encourage teachers to guarantee the quality and efficiency of team building, to promote the depth and breadth of the integration of the industry and the construction of the team.
\end{abstract}

Keywords-applied undergraduate universities, double type, teachers team construction

\section{INTRODUCTION}

With the development of economy in our country, social demand for talent has undergone important changes. To train tens of millions of application-oriented talents with innovative awareness and ability, who master the basic knowledge and skills of production line and can meet the development of industry, has become the urgent need of the social and economic development. The coexistence of College Students' Difficulty in Employment and "labor shortage" phenomenon reflects structural unemployment in the labor market, one of the reasons of which is its lack of application-oriented talents. Universities are the output mechanism of talents, which bear important responsibilities of training comprehensive, application-oriented, innovative and skilled personnel. Therefore, we must change the thinking of higher education development, strengthen the training of applied talents, and create a high-quality workforce, in order to serve the development of local economy and society. But in fact, there is a general problem in the cultivation of talents' application, practice and innovation ability in China's Universities, the fundamental reason of which is that the construction of teachers did not meet the training requirements for talents. How to improve the quality of personnel training and provide a large number of applications versatile talents for the community "production" , the key is to build a " double type" teacher team with high academic level and the ability of social practice and application.

\section{Connotation OF “DOUble Type” TeAchers}

The State Education Department explained "double type" teachers many times, which can be classified as three types. First, double-certificate teachers. Teachers need to also have the teacher qualification certificate and industry certifications. Second, dual grade teachers. Teachers need to have the title of lecturer (upwards) and professional titles above the intermediate level. Third, applied research-type teachers. Teachers need to have the teacher qualification certificate and preside over the application of research, and put it into practice in business [1]. These three types of "double type" teacher's explanation are not comprehensive.

We believe that "double type" is a quality, a kind of practicing. For the definition of this connotation, some indicators are rigid, explicit, quantifiable, such as the teacher qualification certificate; industry or professional certification, and the ability to undertake research or applications. Some indicators are also soft, hidden, non-quantifiable, which is the "double type" teacher's professionalism. Therefore, we believe that the "double type" teachers have the quality and professionalism of teachers, know well the forefront of the industry, and strong practical ability

\section{SignifiCANCE OF “DOUBle TyPE” TeACHERS TEAM CONSTRUCTION IN APPLIED UNIVERSITIES}

First of all, the "double type" teacher's team construction is an important prerequisite to achieve training objectives of 
undergraduate universities. There are two kinds of the compositions of applied undergraduate colleges. One is the original ordinary colleges. Teachers of these schools generally have a high level of theory, but weak in practice. Another kind is these colleges promoted from the original higher vocational school. Teachers of such schools have strong practical ability, while the theoretical level is weak.

Secondly, the "double type" teachers training are requirement of self-development for teachers. The running orientation of applied colleges is to develop applicationoriented talents, which put forward higher requirements for the teachers. Teachers must not only have profound professional theoretical level, but also a wealth of practical ability.

Thirdly, the "double type” teacher's construction is in favor of implementation of the "double certificates" system. "Double Teachers" is exemplary. They can give step-by-step directions for students in teaching theoretical knowledge and practical skills, and urge the improvement of students' theoretical level and practical skills, which helps students successfully get the "double certificates."

\section{Problems of "Double Type" Teachers Team CONSTRUCTION IN APPLIED UNIVERSITIES}

\section{A. No uniform standard for the identification of "double type" teachers}

Although the education departments at all levels put forward a very high demand for "double type" teachers, there is no document issued specially for the identification of "double type" teachers. Main Points in the Education in Shandong Province explained “double type" teachers Team Building for three years since 2013, and gradually to advance "double type" Teachers Team Building. They are In 2013, the long-term mechanism of "double type " teachers team Construction of Vocational Education; In 2014, the Strengthening of "double type " teachers Team Construction in Vocational Education; In 2015, the Promoting of "double type " teachers Team Construction in Vocational Education. There was no relevant provision for the identification of "double type" teachers, so the applied universities are unclear and generate their own standards in the training and selection of "double type" teachers.

\section{B. Unreasonable training mechanism of "double type" teachers}

Many applied undergraduate education send their teachers to be tempered through titular position, or for the practice in operating post in enterprises, and other measures. But these measures usually become a mere formality, and can't play a practical effect. Moreover, the number of professional counterparts' enterprises is small. For corporate trade secrets, enterprises have reservations the teachers in many practice aspect, this mechanism can't enhance the teachers' practice capability.

\section{Imperfect incentive mechanism of "double type" teachers}

The wage structure, job promotion, assessment oversight system of "double type" teachers is not perfect [2], resulting in teachers' enthusiasm in enhancing professional practice ability is not high. This is an important reason limited growth and promotion of "double type "teachers.

\section{Measures of "Double Type" Teachers Team CONSTRUCTION IN APPLIED UNIVERSITIES}

\section{A. To make clear identified standards, strengthen the "double type " consciousness}

Education authorities should issue as soon as possible methods of identification, training and management for "double type", formulate a unified "double type" teachers recognized standards, and indicate the direction for schools. We think that "double type" teachers can be identified in the following three aspects: First, double-certified teachers. Teachers need to have teacher's certificate and industry certifications. Second, dual grade teachers. Teachers need to have more than the title of lecturer and professional titles above the intermediate level. Third, applied research type teachers. Teachers need to have teacher's certificate and preside over the application of research, which should be applied in practice in business [3]. No matter what kind of identification, teachers are required to have profound theory and rich practical skills.

Application oriented university teachers must change their ideas, to correct the idea that as long as you get a Teacher's Certificate or professional qualification certificate, then you can be included in the" double type " teachers range. In the assessment of the qualifications of "double type" teachers, in addition to the above-mentioned certificate, the university should also establish a special practical operation evaluation mechanism, take the practical operation assessment as an important content, hold practical operation assessment for teachers who get qualified regularly every year, link to the firms, make the corresponding professional teaching ability to operate on a real job as the main content of the assessment, and choose teachers with higher score in the practical operation assessment as "double-type" teachers, and make them "double type "teachers with both double certificate and double quality.

\section{B. To innovate training model and improve the training system}

Teachers' professional training should be carried out in many forms. Qingdao Huanghai University where the author works in uses a "five-layer formula" training strategy and supporting measures to improve teachers' skills. First, take advantage of the existing resources of the school training base to improve the basic skills. Second, using holiday time, through the way of hiring experts of companies and industry into the school, the school established professional training camp, so the professional theory and professional practice of the professional teachers can be promoted further. Third, arrange professional teacher to attend regularly scheduled professional learning and skills training, to dig deeply the frontier knowledge and the future development trend of each specialty. Fourth, to arrange teachers go to the businesses for a period of 2 to 3 months of testing and training during the school summer vacation. Teachers can master professional knowledge and skills, at the same time, get the knowledge and talent needs of jobs. Fifth, the technician identification, which asks teachers to 
attend the exam. The identification process of technicians and senior technicians is the assessment of the knowledge and skills that the teachers get in the previous four stages, but also a sublimation of the professional skills of teachers which helps teachers once again improve their comprehensive ability to achieve the standards of "double-type" teachers, and fulfill faculty development goals.

Strengthen bilateral depth substantive cooperation between schools and enterprises, and take the road of integration research. Encourage teachers to declare research projects with businesses, and participate in project design, to find comprehensive graduation practice from the production practice for the students. To encourage teachers to go out of school, to be business-oriented and production-oriented, to undertake research projects actively, to engage in scientific research and technical services, to study technology in-depth , to research and develop new products and new technology. To encourage teachers to carry out various types of external professional and technical development services[4]. Advantages of combination of research: First, to achieve the combination of the research work and teaching, this helps teachers in teaching innovation, and exploring ways to solve problems, and improving the quality of teaching. Second, to carry out applied research and technical services through cooperation with enterprises, this improves the research capacity of teachers and the promotion of the use of scientific research. Third, to achieve the combination of teachers' scientific research work and the practical needs of business, and to achieve effective research transformation through the technology and equipment of professional teachers, which is conducive for energy conservation and improvement of product quality, development of new products, so as to serve the local economy and strengthen the willingness of companies’ partnerships.

\section{To broaden the motivation, assessment mechanism and promote teachers' self-improvement}

Applied Universities should broaden the incentive system, to give preferential policies in the wage structure, job evaluation, and academic exchanges, to promote teachers' professional capacity. Practical undergraduate teaching should be different from general undergraduate education and higher vocational education, which requires a solid professional, comprehensive, theoretical level, undergraduate education and vocational education; teachers are required to solid professional, comprehensive, high theoretical level. At the same time, teachers need to go into professional practice and grasp the development trend of the industry, and use it flexibly in the practical teaching [5]. Both teachers' professional development and professional growth need teachers to adapt to the development of the school, and constantly improve their professional theoretical level and professional practice ability. Establish assessment mechanism, to make quantitative evaluation, and set up the use mode of double teacher teachers. If the assessment standards are met, then the one can enjoy the treatment of "double -type" teachers. If the assessment standards are not met, the treatment should be canceled. Such an assessment mechanism can prompt teachers to continuously improve their own quality, improve teaching quality, and accomplish the training goal of applied talents.

\section{SUMMARY}

The development of "double type" teacher team construction work relates to the quality of construction of teacher team in vocational schools, relates to the merits of the quality of vocational education, and relates to the construction of modern vocational education system. From the government point of view, that is to perfect the relevant policies and regulations for the construction of the teaching staff in the application oriented universities; to establish "double-type" teachers training system, and to increase financial investment and establish multi-channel financing mechanism. From the perspective of application oriented universities, that is to broaden access to vocational school teachers, to further optimize the structure of teaching staff. Undertake the teachers training in depth, and promote "double qualification" of vocational school teachers and perfect management system of teachers, and guide the vocational teachers towards the "double" reasonably. From the teacher's point of view, that is to further deepen the understanding, to improve their professional level, in order to enhance the quality of "double-type" teachers[6].To Integrate favorable factors, take effective measures, and guarantee high quality and high efficiency of the construction. From the perspective of enterprise and industry, that is to further change the role of the enterprise, deepen the content and form of the teacher going to the enterprise practice. The industry should strengthen supervision and guidance, and broaden the channels of social support, to create an effective force jointly.

Applied colleges should keep up with oriented policy, be based on the orientation, carefully analyze the existing problems of "double type "teachers construction, use various forms to strengthen the training of teachers' professional theory and practical ability, broaden incentives and evaluation mechanism of "double type" teachers, strive to improve the quality of teaching, fulfill the training goal of application talents.

\section{REFERENCES}

[1] [2015] No. 6, "the Ministry of Education on Deepening Vocational Education Reform, a number of observations to improve training quality talent"

[2] Cha wenjing. etc. Situation and Countermeasures of Higher Vocational College Double-type Teachers [M]. Changchun Institute of Education.

[3] [2008] No.5 teach high "on the issuance of the Ministry of Education Personnel in Higher Vocational Colleges evaluation project notice"

[4] Li Mengqing Zhang Bizhu. "Double Type" teachers' team construction system of the review and reflection [J]. Journal of education and profession, 2012 (6): 16

[5] Dai Jianping. On higher vocational college "double type" teachers team construction of thinking $[\mathrm{J}]$. Science and technology intelligence development and economy, 2008 (13): 26

[6] Luo Jiangdao, Zhong Wenji. The construction of "double type" teachers of the ways and measures. China's vocational and technical education, 2010 (2): 83-84 